\title{
Invasive bivalves in fresh waters: impacts from individuals to ecosystems and possible control strategies
}

\author{
Ronaldo Sousa $\cdot$ Adriana Novais $\cdot$ Raquel Costa $\cdot$ \\ David L. Strayer
}

Received: 11 July 2012/Accepted: 25 November 2012/Published online: 22 January 2013

(C) Springer Science+Business Media Dordrecht 2013

\begin{abstract}
Invasive bivalves may cause great ecological, evolutionary, and economic impacts in freshwater ecosystems. Species such as Corbicula fluminea, Dreissena bugensis, Dreissena polymorpha, Limnoperna fortunei, and Sinanodonta woodiana are widely distributed hyper-successful invaders, but several others not yet invasive (or at least not considered as such) may become so in the near future. These species can affect hydrology, biogeochemical cycling, and biotic interactions through several mechanisms, with
\end{abstract}

Guest editors: Manuel P. M. Lopes-Lima, Ronaldo G. Sousa, Simone G. P. Varandas, Elsa M. B. Froufe \& Amílcar A.

T. Teixeira / Biology and Conservation of Freshwater Bivalves

R. Sousa $\cdot$ A. Novais

CBMA - Centre of Molecular and Environmental

Biology, Department of Biology, University of Minho,

Campus de Gualtar, 4710-057 Braga, Portugal

R. Sousa $(\bowtie)$

CIIMAR/CIMAR - Interdisciplinary Centre of Marine and Environmental Research, University of Porto,

Rua dos Bragas 289, 4050-123 Porto, Portugal

e-mail: ronaldo.sousa@ciimar.up.pt

\section{R. Costa}

CIEPQPF, Department of Chemical Engineering, University of Coimbra, Pólo II, Rua Sílvio Lima, 3030-790 Coimbra, Portugal

\section{L. Strayer}

Cary Institute of Ecosystem Studies, P.O. Box AB, Millbrook, NY 12545, USA impacts ranging from individuals to ecosystems. Freshwater invasive bivalves can create no-analog ecosystems, posing serious difficulties for management, but new techniques are becoming available which may enhance options to detect early introductions and mitigate impacts. Although knowledge about the biology of these bivalves has increased considerably in the last two decades, several fundamental gaps still persist; we suggest new research directions that are worth exploring in the near future.

Keywords Bivalves - Corbicula fluminea .

Dreissena $\cdot$ Impacts · Invasive species · Limnoperna fortunei $\cdot$ Sinanodonta woodiana

\section{Introduction}

Biological invasions are a significant component of global change, imposing a serious threat to the conservation of biodiversity (Simberloff et al., 2013). Numerous studies have summarized the impacts of invasive species at the individual, population, community, and ecosystem levels (Ehrenfeld, 2010; Simberloff, 2011; Sousa et al., 2011a; Strayer, 2012) and others have highlighted the great economic impacts generated by these pests (Pimentel et al., 2000; Vilà et al., 2010). The importance of these species has led to an increase in the number of studies dealing with biological invasions in recent decades 
(e.g., Richardson \& Pyšek, 2008). In addition, invasive species management and control is now one of the biggest challenges faced by conservation biologists and there is an increasing pressure on policy makers to regulate and mitigate this component of global change (Hulme et al., 2009).

Aquatic ecosystems have been subjected to hundreds of introductions of invasive species (Strayer, 2010). These introductions are related to human activities (e.g., trade, aquaculture, construction of canals, aquarium releases, sport fisheries, recreational activities, ballast water) that deliberately or accidentally transported these species worldwide (Cohen \& Carlton, 1998; Kolar \& Lodge, 2002). As freshwater ecosystems already undergo multiple impacts resulting from pollution, habitat loss and fragmentation, water regulation, climate change, and overexploitation of resources, the addition of invasive species can further alter existing ecosystem functions and services (Dudgeon et al., 2006).

Among the various taxonomic groups that have been introduced in fresh waters, ecological and economic impacts due to bivalves are well-documented (Keller et al., 2007a; Strayer, 2010). Invasive bivalves are widely recognized by their biofouling activity in water-dependent industries, such as power stations, waterworks, and pulp and paper mills (Connelly et al., 2007; Mackie \& Claudi, 2010; Mansur et al., 2012), as well as by being an important threat to native biodiversity (Ricciardi et al., 1998). The economic and environmental costs of invasive freshwater bivalves are increasing worldwide as a growing number of species is transported beyond their respective native range. Given the importance of these pests, this paper aims to (i) present a brief literature review about the most problematic invasive freshwater bivalves and summarize their distribution; (ii) describe the major mechanisms of ecological impact; (iii) discuss their main effects from the individual to the ecosystem level; (iv) suggest possible control measures for application in the ecological context, and (v) address future avenues for research.

\section{Literature review}

We completed a bibliometric survey using the ISI Web of Knowledge database and assessed the papers dealing with the five most studied freshwater invasive bivalves until December 31, 2011. In this survey, each study was classified according to its year of publication, geographic area of origin, and theme addressed.

This bibliometric survey showed that invasive bivalves in freshwater ecosystems have received extensive scientific attention in recent years, as shown by a rapidly increasing number of papers published on the subject (Fig. 1). The zebra mussel Dreissena polymorpha is by far the most studied species, followed by the Asian clam Corbicula fluminea, the quagga mussel Dreissena bugensis, the golden mussel Limnoperna fortunei, and the Chinese pond mussel Sinanodonta woodiana (Fig. 1). Although these species constituted the major part of the published studies so far, it is possible that other species still out of the headlines could became a nuisance and receive more scientific attention in the future. Indeed, given the pace that many fishes have been transported around the planet it is possible that more unionid species (mainly those species that use a large range of hosts or those that use widely transported fish species) will become established and expand their distribution.

Not surprisingly, the major themes studied are dominated by ecology and conservation; management (included in the term "others") has received little attention (Fig. 2). However, a vast number of studies dealing with management are available in

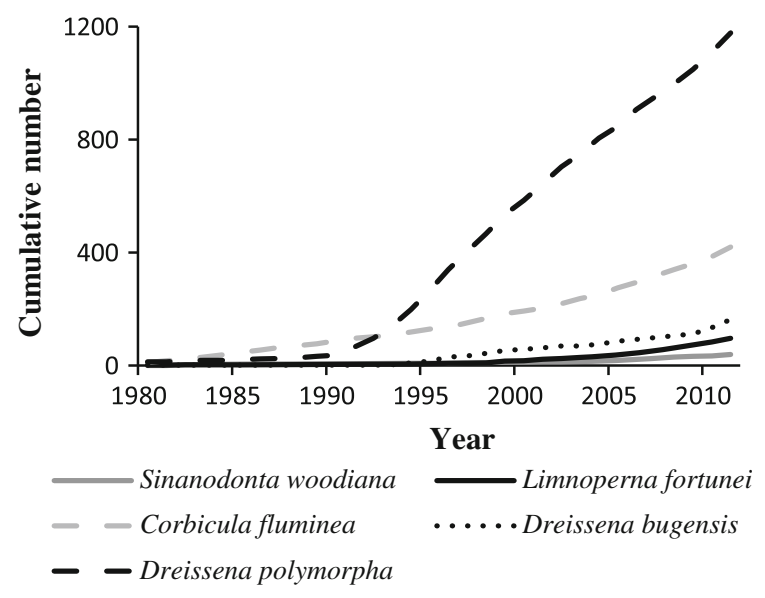

Fig. 1 Cumulative number of publications addressing freshwater invasive bivalves from Web of Science until December 31, 2011. Search terms C. fluminea $(n=419)$, D. bugensis $(n=162)$, D. polymorpha $(n=1177)$, L. fortunei $(n=96)$, and $S$. woodiana $(n=38)$ 
Fig. 2 Percentage of publications by selected theme from Web of Science until December 31, 2011 for C. fluminea, D. bugensis, D. polymorpha, L. fortunei, include themes such as systematics, anatomy, morphology, and management of impacts and $S$. woodiana. "Others"

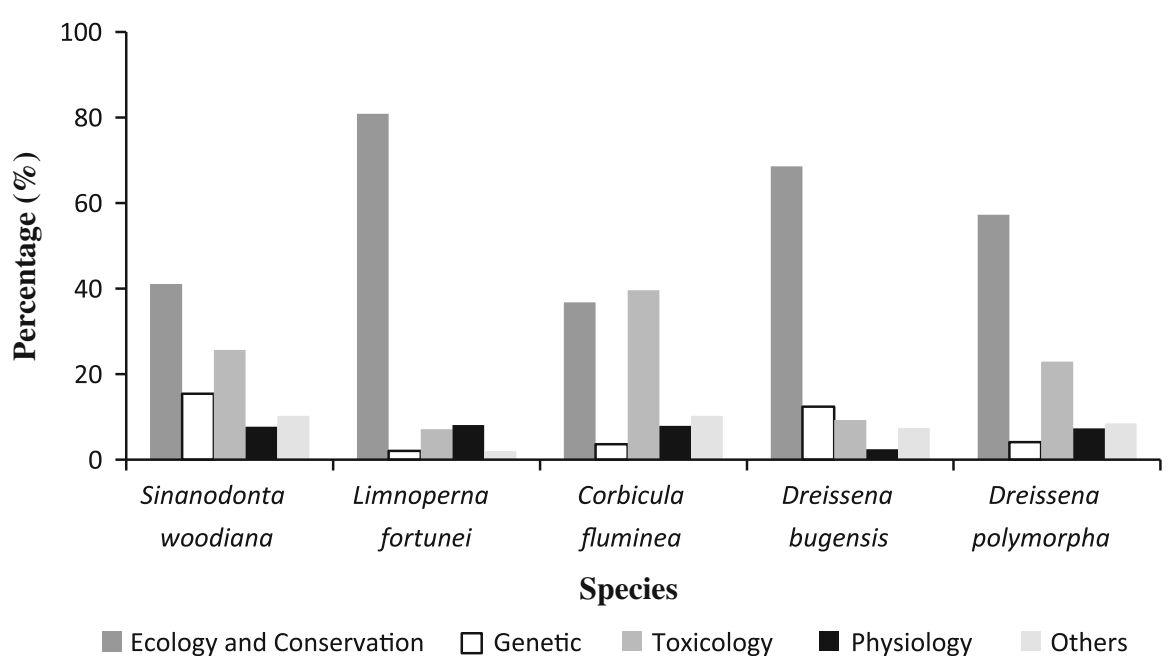

gray literature (not covered by ISI Web of Knowledge) and there is a need to increase the efforts to publish these studies more frequently in scientific journals.

North America and Europe still lead in terms of the percentage of published studies (exceptions are $L$. fortunei in South America and S. woodiana in Asia) (Fig. 3). The number of studies in a particular geographic area seems to be a function of where the species is most widespread, most abundant, and causing the most serious ecological and economic problems. Also, we cannot forget that the financial investment applied to research is much higher in North America and Europe and so it is expected that the effects of invasive species are much more studied in these geographic areas.

\section{Distribution and successful establishment of invasive freshwater bivalves}

Invasive freshwater bivalves are now present in all continents (with the exception of Antarctica) and some oceanic islands, colonizing both lotic and lentic habitats. In recent decades, several species have attained great densities, biomass, and spatial distribution, being usually described as problematic (Table 1). Other species, although introduced into different parts of the world, are still not considered threats because their ecological or economic impacts have not been described or remain unknown (Table 1).

Data on invasive freshwater bivalves' distribution do exist (see Ilarri \& Sousa, 2012 for C. fluminea; Mills et al., 1996 and Zhulidov et al., 2010 for
Fig. 3 Percentage of publications by geographic area of the study, from Web of Science until December 31, 2011 for $C$. fluminea, $D$. bugensis, D. polymorpha, $L$. fortunei, and $S$. woodiana. Very few publications were from Oceania, so this continent was removed from the figure

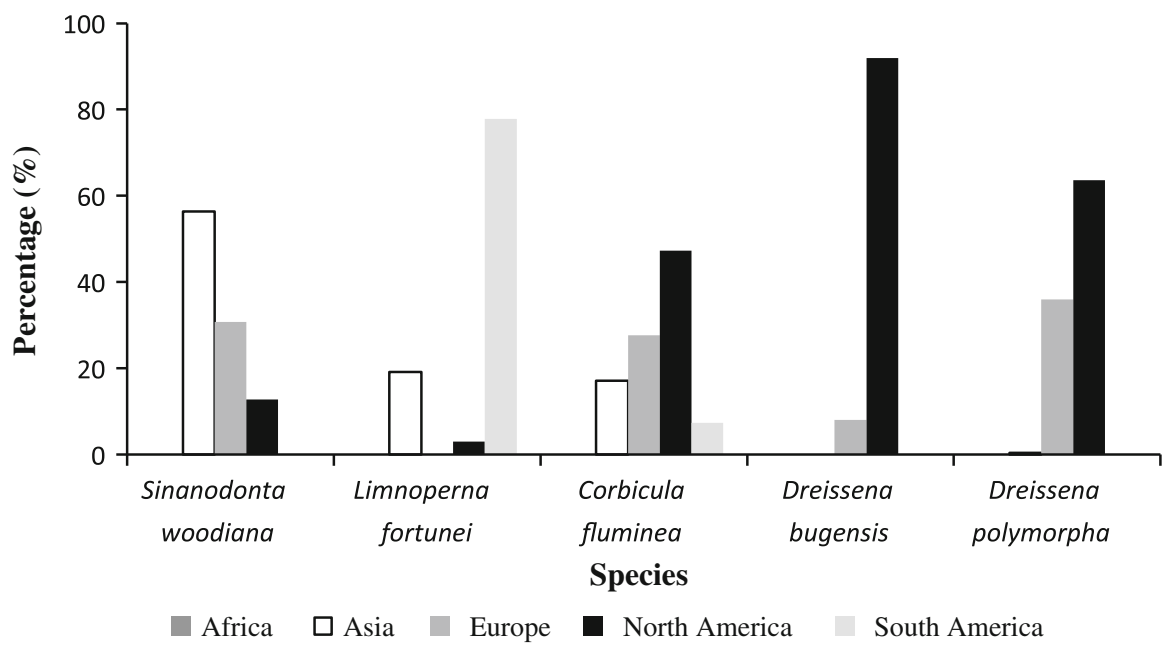


Table 1 Distribution (native and invaded range) of freshwater invasive bivalves

\begin{tabular}{|c|c|c|c|}
\hline Species & Native range & Invaded range & Key references \\
\hline \multicolumn{4}{|l|}{ Corbiculidae } \\
\hline Corbicula fluminea & Asia & $\begin{array}{l}\text { Europe, North and South America, } \\
\text { Africa }\end{array}$ & Sousa et al. (2008a) \\
\hline Batissa violacea & Asia & Polynesia & \\
\hline \multicolumn{4}{|l|}{ Dreissenidae } \\
\hline Dreissena bugensis & $\begin{array}{l}\text { Dnieper River drainage of Ukraine } \\
\text { and Ponto-Caspian Sea }\end{array}$ & Europe and North America & Zhulidov et al. (2010) \\
\hline Dreissena polymorpha & Black, Caspian, and Azov Seas & Europe and North America & Strayer (2009) \\
\hline \multicolumn{4}{|l|}{ Mytilidae } \\
\hline Limnoperna fortunei & $\begin{array}{l}\text { Southeast Asia (China, Laos, } \\
\text { Thailand, Korea, Cambodia, } \\
\text { Vietnam, Indonesia) }\end{array}$ & $\begin{array}{l}\text { Hong Kong, Japan and Taiwan. } \\
\text { South America }\end{array}$ & Boltovskoy et al. (2006) \\
\hline \multicolumn{4}{|l|}{ Sphaeriidae } \\
\hline Eupera cubensis & $\begin{array}{l}\text { Fresh waters of the Atlantic } \\
\text { drainage from Texas to North } \\
\text { Carolina, and in Central and } \\
\text { northern South America }\end{array}$ & $\begin{array}{l}\text { Chicago Sanitary and Ship Canal } \\
\text { (northern Illinois, USA) and the } \\
\text { Monongahela River (northern } \\
\text { West Virginia, USA) }\end{array}$ & Mills et al. (1993) \\
\hline Pisidium amnicum & Eurasia and North Africa & $\begin{array}{l}\text { Great Lakes, Lake Champlain and } \\
\text { Hudson River (USA) }\end{array}$ & Mills et al. (1993) \\
\hline Pisidium henslowanum & Eurasia & Great Lakes (USA) & Mills et al. (1993) \\
\hline Pisidium moitesserianum & Eurasia & Great Lakes (USA) & Mills et al. (1993) \\
\hline Pisidium punctiferum & Central America & Florida and Texas (USA) & Strayer (1999) \\
\hline Pisidium supinum & Eurasia & Great Lakes (USA) & Mills et al. (1993) \\
\hline Sphaerium corneum & Eurasia & $\begin{array}{l}\text { Great Lakes and also Lake } \\
\text { Champlain, and Hudson River in } \\
\text { New York (USA) }\end{array}$ & Mills et al. (1993) \\
\hline \multicolumn{4}{|l|}{ Unionidae } \\
\hline Alasmidonta marginata & Mississippi and St. Lawrence basins & $\begin{array}{l}\text { Hudson River (USA). Probably } \\
\text { migrated naturally via the Erie } \\
\text { Canal }\end{array}$ & Mills et al. (1997) \\
\hline Fusconaia flava & $\begin{array}{l}\text { Mississippi River, Great Lakes, and } \\
\text { Hudson Bay basins }\end{array}$ & $\begin{array}{l}\text { Hudson River (USA). Probably } \\
\text { migrated naturally via the Erie } \\
\text { Canal }\end{array}$ & Mills et al. (1997) \\
\hline Lampsilis cardium & Mississippi and St. Lawrence basins & $\begin{array}{l}\text { Potomac River basin; Hudson River } \\
\text { (USA) }\end{array}$ & Strayer (1999) \\
\hline Lasmigona subviridis & $\begin{array}{l}\text { Atlantic Slope and Kanawha River } \\
\text { basins }\end{array}$ & $\begin{array}{l}\text { Lake Ontario drainage, Erie Barge } \\
\text { Canal at Syracuse, Chittenango } \\
\text { Creek (Kirkville, New York) and } \\
\text { in the Finger Lakes area in New } \\
\text { York State (part of the Lake } \\
\text { Ontario drainage); possibly } \\
\text { Watauga River, Tennessee (USA) }\end{array}$ & Mills et al. (1993) \\
\hline Leptodea fragilis & Mississippi and St. Lawrence basins & $\begin{array}{l}\text { Oneida Lake and the Hudson River } \\
\text { in New York. May have been } \\
\text { introduced via the Erie Canal } \\
\text { (USA) }\end{array}$ & Benson (2012) \\
\hline Ligumia nasuta & $\begin{array}{l}\text { Atlantic Slope and St, Lawrence } \\
\text { basins }\end{array}$ & $\begin{array}{l}\text { Upper Allegheny River basin } \\
\text { (USA) }\end{array}$ & Strayer \& Jirka (1997) \\
\hline Ligumia recta & $\begin{array}{l}\text { Mississippi, St. Lawrence, and } \\
\text { Hudson Bay basins }\end{array}$ & $\begin{array}{l}\text { Oneida Lake (USA). May have } \\
\text { been introduced via the Erie } \\
\text { Canal }\end{array}$ & Benson (2012) \\
\hline
\end{tabular}


Table 1 continued

\begin{tabular}{|c|c|c|c|}
\hline Species & Native range & Invaded range & Key references \\
\hline Potamilus alatus & Mississippi and St. Lawrence basins & $\begin{array}{l}\text { Oneida Lake and the Hudson River } \\
\text { in New York (USA). May have } \\
\text { been introduced via the Erie } \\
\text { Canal }\end{array}$ & Benson (2012) \\
\hline Pyganodon grandis & $\begin{array}{l}\text { Mississippi, St. Lawrence and } \\
\text { Hudson Bay basins }\end{array}$ & Hudson River (USA) & Benson (2012) \\
\hline Sinanodonta woodiana & $\begin{array}{l}\text { Eastern Asia, primarily from the } \\
\text { Amur River and Yangtze rivers }\end{array}$ & $\begin{array}{l}\text { Europe (Spain, France, Italy, } \\
\text { Germany, Austria, Slovakia, } \\
\text { Hungary, Czech Republic, } \\
\text { Poland, Croatia, Serbia, Romania, } \\
\text { Moldova, Ukraine and Sweden), } \\
\text { Central America (Dominican } \\
\text { Republic and Costa Rica), } \\
\text { Indonesia and recently North } \\
\text { America (fish farm in Franklin } \\
\text { Township, New Jersey, USA) }\end{array}$ & Lajtner \& Crnčan (2011) \\
\hline
\end{tabular}

It is possible that additional introductions of unionids occurred through fish stocking but this information is still unreported because of deficient knowledge on their natural ranges

D. bugensis; Strayer, 2009 and Aldridge et al., 2004 for D. polymorpha; Boltovskoy et al., 2006 and Mansur et al., 2012 for L. fortunei; Lajtner \& Crnčan, 2011 for S. woodiana) although gaps of information in some continents (Africa and Asia) still persist. For the purpose of this paper we will briefly summarize the major native and invaded ranges of these five hypersuccessful invasive bivalve species.

Corbicula fluminea is native to Asia and has been dispersed nearly worldwide. The first documented occurrence outside its native range was in the Pacific coast of United States in the 1920s; 40 years later, its distribution had extended to the Atlantic coast (McMahon, 1982). In South America, this genus was first noticed around the 1970s (Darrigran, 2002) and in Europe its presence was described for the first time in the early 1980s (Mouthon, 1981). In the Americas this species is present from Patagonia in the south to Canada in the north, and in Europe it is present from Portugal in the west to Romania in the east, including the United Kingdom and Ireland in the north (Ilarri \& Sousa, 2012). Recently, Clavero et al. (2012) described its presence in two Moroccan rivers (Africa). Taxonomic uncertainties still exist in the genus Corbicula, which complicates the detailed description of the species distribution in the native and invaded ranges (see for example Pigneur et al., 2011).

$D$. bugensis and D. polymorpha are native to the Ponto-Caspian region and have been introduced in
Europe and North America (USA and Canada). D. polymorpha's distribution is better documented. The species is widespread in North America (mainly in the East and Midwest; reviewed in Strayer, 2009) and in Europe, where it is present in the north-west Russia, central and western Europe (with the exception of Portugal), Scandinavia, UK and Ireland (reviewed in Aldridge et al., 2004). D. bugensis also has spread widely outside of its native range in western Europe and North America, and in some places this species is replacing D. polymorpha (Mills et al., 1996; Zhulidov et al., 2010).

Limnoperna fortunei is native to the rivers and estuaries of Southeast Asia (China, Thailand, Korea, Laos, Cambodia, Vietnam and Indonesia). It was introduced to fresh and brackish waters in Hong Kong, Taiwan, and Japan between 1965 and 1990, and subsequently invaded South America in 1989-1990, being present in Argentina, Uruguay, Paraguay, Bolivia, and Brazil (reviewed in Boltovskoy et al., 2006).

Sinanodonta woodiana is native to southeastern Asia (China, Korea, Japan, Taiwan and Eastern Russia) and has colonized Europe (Spain, France, Italy, Germany, Austria, Slovakia, Hungary, Czech Republic, Poland, Croatia, Serbia, Romania, Moldova, Ukraine, and Sweden), Central America (Dominican Republic and Costa Rica), Indonesia and recently North America (reviewed in Lajtner \& Crnčan, 2011). 
This species belongs to the family Unionidae, which has a completely different life cycle than the previous species since $S$. woodiana needs a fish host to complete its larval development.

Information about other invasive species that usually are not described as hyper-successful is shown in Table 1.

Usually, the success of invasive species in the introduced range may be explained in terms of two sets of aspects that may act synergistically: (i) the traits of the invasive species and/or (ii) the characteristics of the invaded area. For bivalves (as other species), the most important traits that have been linked to invasive success include the ability to colonize a vast range of habitats, high genetic variability and phenotypic plasticity, great physiological tolerance to abiotic changes, short-generation times, rapid growth, rapid sexual maturity, and great fecundity, association with human activities and high dispersal potential; these traits are usually related with an opportunistic behavior ( $r$ strategists) (McMahon, 2002). Keller et al. (2007b) showed that fecundity of molluscs may be the key factor for the successful establishment and subsequent development into a nuisance in the Great Lakes. As far as the characteristics of the invaded areas are concerned, the following aspects are believed to favor invasive species establishment: great number of transport vectors, sparse recipient communities, high levels of disturbance, availability of empty niches, and low species richness (although several exceptions have been described for plants; Stohlgren et al., 1999), great similarity between the receptor and donor habitats, and the absence of enemies (e.g., predators, parasites, and competitors) (Byers, 2002). Finally, the fundamental role of propagule pressure (i.e., introduction effort, which is related to the total number of individuals introduced in conjunction to the number of introduction attempts; Simberloff, 2009) is central to the establishment and dispersion of invaders, and is expected to be important for freshwater bivalves.

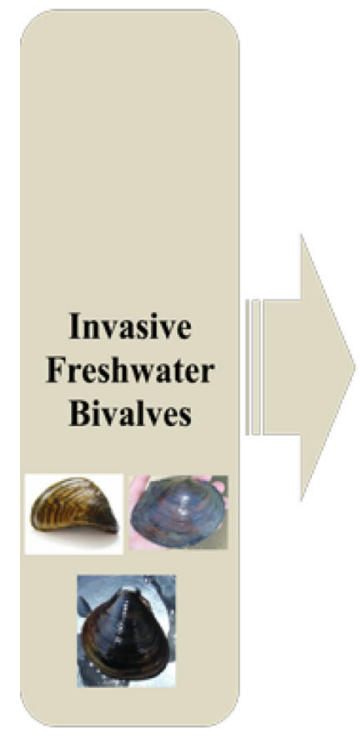

\section{Filtration \\ Bioturbation \\ Shells \\ Feces and pseudofeces \\ Resource subsidy \\ Bioamplification and biomagnification of contaminants \\ Biotic interactions (e.g. predator/prey; introduction of diseases and parasites)}

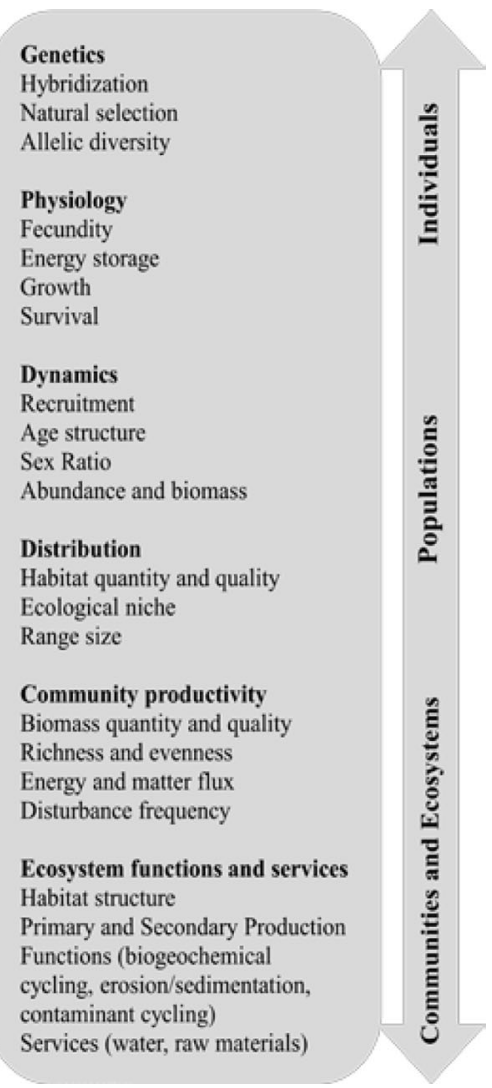

Fig. 4 Summary of some of main mechanisms of impact by invasive freshwater bivalves and their likely effects on different levels of biodiversity 


\section{Main mechanisms of ecological impact}

Invasive bivalves can be responsible for many changes in the invaded area through a variety of mechanisms, including capture and consumption of suspended particles, ecosystem engineering, production of feces and pseudofeces, functioning as an important resource subsidy, bioamplification of pollutants throughout the food chain and various biotic interactions (Fig. 4). These mechanisms have reverberating effects at the individual, population, community, and ecosystem levels (Fig. 4).

Bivalves being important filter-feeders in freshwater ecosystems may be responsible for the control of the concentration and composition of suspended particles (Strayer et al., 1999). Many studies with C. fluminea (Phelps, 1994), D. polymorpha (Karatayev et al., 1997), and L. fortunei (Boltovskoy et al., 2009) have shown that these species may be responsible for important changes in the concentration of phytoplankton, zooplankton, and organic and inorganic particles, moving suspended matter from the water column to the benthos.

Bivalves are well-recognized as important ecosystem engineers (organisms that change the abiotic environment by physically altering structure and thus modifying, maintaining, and creating habitats; Jones et al., 1994). The most important engineering mechanisms through which they act are related to water filtration, bioturbation of sediments, and provision of shells (Sousa et al., 2009).

Bivalves also produce a great quantity of feces and pseudofeces, which may have great effects on the invaded habitat mainly by altering biogeochemical cycles and by promoting sedimentation (Prokopovich \& Herbert, 1965; Roditi et al., 1997).

Although this is still a largely unexplored topic, invasive species can be a resource subsidy between different habitats, functioning as an important transfer route for food, nutrients, and energy between aquatic and adjacent terrestrial ecosystems. For example, several invasive bivalves can undergo massive dieoffs during extreme climatic events, which result in the availability of great biomass that can be consumed by a myriad of organisms. This biomass can be important for terrestrial animals and also for scavengers, detritivores, and plants that can use the nutrients (including calcium from the shells). Studies addressing this issue are rare, but the biomass resulting from these massive die-offs may reach dozens of kilograms per $\mathrm{m}^{2}$ (Ilarri et al., 2011; Sousa et al., 2012; Bódis et al., 2013).

Invasive bivalves can accumulate contaminants, thus bioamplifying them along the food chain with important impacts on higher trophic levels. In San Francisco Bay, Corbula amurensis traps selenium (even at low concentrations) because this species has lower rate of loss of this element, and thus affects several of its predators (Stewart et al., 2004). Although C. amurensis is a brackish-water species, it is possible that freshwater invasive bivalves have similar effects on the bioamplification and biomagnification of contaminants in food chains (Morrison et al., 1998).

Finally, invasive bivalves can change biotic interactions. A well-studied biological interaction resulting from the introduction of freshwater invasive bivalves is the infestation of native bivalve species by $D$. polymorpha and L. fortunei, which poses a serious threat to their conservation (Karatayev et al., 2007; Sousa et al., 2011b). Some studies show that the invasive bivalves can be consumed by predators and thus change the existing predator/prey interactions (Sylvester et al., 2007a; Carlsson et al., 2009, 2011). Other studies show that the invasive species alter phyto- and zooplankton communities due to top-down effects (Phelps, 1994; Caraco et al., 1997, 2006; Karatayev et al., 2007). They may also introduce new parasites and diseases that can affect native species (and themselves be affected by native diseases and parasites; Sousa et al., 2008a).

As expected, the magnitude of the ecological effects by invasive bivalves depends on the abundance, range, functional distinctiveness, resident biota, physical characteristics of habitat, and time passed since invasion. However, studies showing this context dependency are rare and this topic deserves further attention, especially the possible importance of time since introduction. In fact, many introduced populations remain restricted, not posing serious problems for extended periods of time but suddenly may become problematic (Strayer et al., 2006; Essl et al., 2011); this may also be the case of introduced bivalve species. On contrary, some studies reported extensive impacts few years after introduction (e.g., zebra mussels in Europe and North America), but in the long-term the population may stabilize with a much smaller density in comparison with the first years after invasion and overall impact start to decrease (Karatayev et al., 1997). 


\section{Major impacts at different ecological levels}

Individual level

Invasive species may hybridize with native species. Many examples have been described for aquatic ecosystems; plant, crayfish, and fish species being the best known (Rhymer \& Simberloff, 1996; Perry et al., 2002; Cox, 2004). We are not aware of many examples coming from freshwater bivalves but different species may hybridize (e.g., Alasmidonta varicosa and A. marginata; Pyganodon cataracta and P. grandis; Lampsilis cardium and L. cariosa; and Lampsilis radiata and L. siliquoidea; Kat, 1986; Strayer \& Fetterman, 1999; Clayton et al., 2001). Corbicula may also hybridize and it is possible that in the invaded and native ranges, different Corbicula species may originate new lineages (Sousa et al., 2008a). Overall, this phenomenon of hybridization is probably much more widespread than yet recognized among freshwater bivalves and special attention should be given to possible translocations concerning endangered freshwater unionid mussels that previously were geographically isolated (Perry et al., 2002).

The introduction of invasive freshwater bivalves may also change the natural selection of certain genes. For example, if an invasive bivalve has great filtration rates for particular phytoplankton size classes, this situation may select for genes in the native species that reduce competition and allow coexistence in these new conditions. In the same vein, the great quantity of underused resources (including the invader itself) after invasion may be incorporated in the diets of generalists and even specialists (e.g., fish species exploiting C. fluminea, D. polymorpha or L. fortunei; Carlsson et al., 2009). The high density and biomass of these bivalves can induce morphological and physiological changes in the predators (for example, the selection of morphological characters that permit a change from an omnivorous diet to a diet based on shellfish) which in part may have a genetic basis. However, we are not aware of any study of bivalves that explores the idea of genetic specialization but the potential may exist and deserves attention. This genetic specialization may also occur for native parasites (or introduced parasites coming with the bivalves) that could exploit the availability of a new host and this may be attained by extending their host ranges.

Physiological changes mediated by invasive bivalves have also great importance. For instance, impacts imposed on unionids by zebra mussels are well-recognized, with clear effects on the physiology of the native species in North America and Europe (Ricciardi et al., 1998; Sousa et al., 2011b). D. polymorpha colonizes the posterior end of the unionid shells, and thereby affects filtration rates, hinders locomotion and burrowing behavior, disrupts balance and equilibrium, and causes valve occlusion and suffocation of the unionids, and also has large effects on phytoplankton standing stocks leading to reductions of food resources (reviewed by Schloesser et al., 1996). All these impacts may reduce energy storage, growth rates, fecundity, and ultimately survival (Sousa et al., 2011b). Similar impacts on native bivalve species have been described for $L$. fortunei in South America (Karatayev et al., 2007: Mansur et al., 2012). The effects resulting from infestation may be highly context-dependent, since different native species show considerable variability in mortality rates (Strayer \& Malcom, 2007) and the same could be true for the same species colonizing different sites, suggesting that differences in life history traits, shell morphology, and habitat conditions may be responsible for different responses to fouling (Haag et al., 1993). In any case, fouling by Dreissena or Limnoperna can have profound impacts at the individual level with reverberating effects on the native bivalve community structure.

Also interesting is the possibility of reconfiguring host-parasite relationships by invasive unionids. The European bitterling Rhodeus amarus is a freshwater fish with an unusual relationship with freshwater unionid mussels. Females develop long ovipositors used to place their eggs onto the gills of a mussel, which are then fertilized by males that defend territories around mussels during the spawning season (Smith et al., 2004). Developing embryos reside inside the mussel for 1 month during which time they develop into actively swimming larvae. In a recent study Reichard et al. (2012) showed that the invasive freshwater unionid mussel $S$. woodiana successfully developed on the European bitterling, whereas larvae of the other European unionids were rejected. On the other hand, the fish was unable to use $S$. woodiana as a host in contrast to what happens with other native European unionids. This demonstrates that invasive bivalves may temporarily benefit from a coevolutionary lag by exploiting evolutionarily naïve hosts, which is an example of unexpected consequences for 
established interspecific relationships. Again, these effects may go far beyond the individual level with reverberating effects at the population, community, and ecosystem levels.

\section{Population level}

Several studies with invasive bivalves have shown great impacts on the population dynamics of other species. Dense populations of invasive bivalves can strongly affect the recruitment of other species. Some can clearly benefit from the presence of bivalves' shells to settle on or use as a refuge from predators and adverse abiotic conditions (Ricciardi et al., 1997; Sousa et al., 2009). Others may also benefit from the availability of feces and pseudofeces, which are rich in organic matter (Karatayev et al., 1997). However, recruitment of other species can be impaired because space is already occupied by dense beds of invasive bivalves or the invader may filter the sperm or even larvae of native bivalves, although this last mechanism is still untested (Strayer, 1999).

The sex ratio of native bivalve unionids has been reported to change as a result of the infestation by D. polymorpha. Haag et al. (1993) found greater mortality and lower fitness in $L$. radiata females fouled with zebra mussels, which may affect the population structure.

The aspects described above, along with the possible use of invasive bivalves as a food resource by predators, can completely change the abundance and biomass of populations. Several studies showed that invasive bivalves are consumed by several fish species (Karatayev et al., 1997; Garcia \& Protogino, 2005; Paolucci et al., 2007; Cantanhêde et al., 2008). Also fish larvae can consume bivalve larvae, which in some cases enhances their growth as a result of a higher energy content of the invasive larvae and/or the lower energy costs in capturing the invasive prey as compared to the native ones (Paolucci et al., 2010). This situation results in increased density of several predator species (e.g., in Argentina it was suggested that the presence of L. fortunei increased freshwater fish landings three-fold between 1994 and 2004; Boltovskoy et al., 2006). However, native predators that are unable to exploit this new resource (and if native prey declined) may be in disadvantage and suffer massive declines in density and biomass (Carlsson et al., 2009). Other key predators of these invasive species are waterbirds which in some cases alter their migration patterns to exploit these new resources. For example, D. polymorpha can be highly depleted by bird predation in shallow areas with reductions reaching more than $90 \%$ of bivalve density and with concomitant increases in the density of the waterbirds (Hamilton et al., 1994; Werner et al., 2005). In addition, although largely unexplored, the dynamics of diseases and parasites may be affected, with possible reverberating effects on other hosts (see for example Ogawa et al., 2004).

The introduction of freshwater invasive bivalves may also greatly change the distributions of other species. The habitat can be highly modified by the invasive bivalves (by physical means, for example), which may imply great changes in the habitat quantity and quality available for colonization. Native bivalve species may suffer a great reduction in their distribution due to important changes in the habitat resulting from the presence of invasive bivalve species. For instance, several native bivalves disappeared from deeper areas of the Laurentian Great Lakes after the introduction of zebra mussels, persisting only in nearshore areas (Nichols \& Wilcox, 1997). Likewise, some species that use the novel habitats created by the invasive species may benefit from the new conditions. In a recent study, Ilarri et al. (2012) clearly showed that high densities of $C$. fluminea positively influenced the density, biomass, and number of several macrozoobenthic species (see Karatayev et al., 1997 and Ward \& Ricciardi, 2007 for similar results with D. polymorpha and Sylvester et al., 2007b with L. fortunei).

Community and ecosystem levels

Due to their high filtration rates, invasive bivalves may have significant effects on phytoplankton, reducing the abundance of the species that are directly ingested. However, some species (e.g., cyanobacteria) are not affected or even increase their density in the presence of invasive bivalves, because they are not so palatable (but see Bastviken et al., 1998 and Fernald et al., 2007). These changes occurring at the first trophic level may produce a bottom-up effect with important reverberating modifications in all trophic levels. After the introduction of $D$. polymorpha in the Hudson River, phyto- and zooplankton rapidly decreased with concomitant changes in the higher trophic levels (Strayer et al., 1999). However, after 20 years of 
invasion it appears that the zooplankton is recovering, mainly because the zebra mussel size structure changed during this period (Pace et al., 2010). Similar results have been reported for European ecosystems invaded by $D$. polymorpha (Karatayev et al., 1997).

In addition, as these invasive species attain great densities and biomass, overall secondary production can increase several-fold (Strayer \& Smith, 2001). In the River Minho (Portugal and Spain), C. fluminea attained a secondary production of almost $550 \mathrm{~g}$ ash free dry weight $\mathrm{m}^{-2}$ year $^{-1}$ in 2006 (Sousa et al., 2008b). Although there are no quantitative data before the introduction for comparison, it is reasonable to think that the secondary production in this area increased several-fold (probably $>10$-fold). Such increase may have several implications in ecosystem functioning because a great quantity of biomass is available for direct consumption by higher trophic levels and/or can enter directly the detritus food-web (Sousa et al., 2008b). It is also possible that these invasive bivalves can become an energetic dead end for other trophic levels when predators are not present, or native species of high food value have been displaced (Nalepa et al., 2009).

Filtration by bivalves can increase water clarity due to the decline of particles in the water column. Several comparisons before/after invasive bivalve introduction showed the magnitude of such effect (Phelps, 1994 for C. fluminea; Higgins \& Vander Zanden, 2010 for D. polymorpha; Boltovskoy et al., 2009 for L. fortunei). The increase in water clarity can be responsible for the spread of submerged vegetation (due to an increase in the depth at which macrophytes can grow) and by the enhancement of benthic algal abundance and periphyton (Phelps, 1994; Karatayev et al., 1997; Zhu et al., 2006). In addition, it is possible that nutrients associated with the feces and pseudofeces of invasive bivalves as well as nutrients excreted in soluble forms may increase the overall effect. This change from primary productivity based on phytoplankton to one based on macrophytes and/or benthic algae and periphyton can completely modify the community with reverberating effects at the ecosystem level. As described above, it is possible that many species can be positively affected by the presence of submerged vegetationfishes, for example, may use these new areas as nursery and refuge from predators and stressful abiotic conditions (Strayer et al., 2004).
Also interesting is the possible indirect effect mediated by invasive bivalves on the incidence of diseases. The recent occurrence of botulism in the Great Lakes (USA) has been implicated in large mortalities of waterfowl and fish (Riley et al., 2008). According to Pérez-Fuentetaja et al. (2006), zebra mussels may have enhanced the incidence of botulism type E through (i) the creation of ideal conditions for the proliferation of Clostridium botulinum by the production of feces and pseudofeces (i.e., decomposition from dead mussels and wastes can create bacterial niches where anoxia is prevalent and nutrients are abundant) and (ii) dreissenid mussels have been found to ingest pseudofeces, detritus, and clay particles and thus are exposed to the bacteria and spores present in their own beds. The presence of filter-feeders magnifies the effect of these bacteria through the food chain by being consumed by the invasive round goby (Neogobius melanostomus) and passing the bacteria at higher concentrations to top predators such as birds and fishes. This is an example of an important disease with potential effects at the ecosystem level, where the indirect effect of an invasive bivalve possibly plays an important role. Other examples may exist, with other bacteria, virus, and contaminants, but studies using invasive bivalves rarely address these phenomena.

Invasive bivalves are well-recognized by the great impacts caused on several ecosystem services and can be valued within the ecosystem services framework, and hence labeled as "harmful" or "useful" depending on how the invasion provides a service or a disservice (Duffy, 2009). Filtration by several species can be considered useful because through it the water column is cleared and contaminants are deposited in the sediments in the form of feces and pseudofeces or accumulated in the bivalves' tissue or shells. Approaches have been developed to use these species to combat eutrophication or remove suspended matter from wastewater (Reeders \& Bij de Vaate, 1990, 1992). However, risks may exist due to possible bioamplification and biomagnification of contaminants, which can be harmful.

The increase in water clarity due to filtration may be useful to divers and archeologists because of the higher visibility. However, archeological sites of interest may be negatively affected by the incrustation of bivalves such as D. polymorpha, which may increase decay rates (Mackie \& Claudi, 2010). The 
increase in water clarity and consequent increase in submerged plants may also impede navigation of leisure craft and angling. This may result in increased costs related to waterway maintenance that need mechanical weed cutting. Invasive bivalves can also increase rates of sedimentation [e.g., C. fluminea greatly increased sedimentation rates and enhance accumulation of sediments in the Delta Mendota Canal, California, USA, which required dewatering and removal every 2 years (Prokopovich \& Herbert, 1965)] and so be considered harmful.

When these species attain high densities and distribution, they can be an important food resource for various species, including fish species with commercial value (Boltovskoy et al., 2006). Also, they can be used as a fertilizer, soil amendment or mulch in agriculture or horticulture or to feed livestock (ducks and pigs) and fishes (Mackie \& Claudi, 2010). From these perspectives, these species can be considered useful. On the other hand, it is well-recognized that invasive bivalves undergo massive die-offs during extreme climatic events (Ilarri et al., 2011). The deposition of large biomass of dead tissue in the sediments or even in the banks of rivers and lakes can harm water quality very rapidly due to an increase in nutrients (Cherry et al., 2005; Cooper et al., 2005). The same is true for the great accumulation of shells resulting from these massive die-offs that impair the access to beaches and affect people who use aquatic ecosystems for recreational purposes. Accumulated shells also affect fishing activities due to decrease in the efficiency of nets (Ilarri et al., 2011).

Well-recognized are the problems posed by invasive bivalves (e.g., D. polymorpha and L. fortunei) that attach to solid structures for example in water facilities, dams, and boats. This situation has great economic impacts not only due to biofouling problems but also because of die-offs and subsequent decomposition can occur which may impair water quality (for a review see Mackie \& Claudi, 2010).

\section{Management and control in the ecological context}

Prevention, relying on public awareness, legislation, and monitoring, tends to be the most cost-effective and ecologically viable measure to minimize the spread of invasive species (Finnoff et al., 2007). An integrated management strategy, implemented at a national or regional level, should involve (i) identification of the main dispersal vectors (Carlton, 1993) and accompanying mitigation measures (e.g., educational initiatives, codes of practice for boaters), (ii) recognition of the most vulnerable waterbodies to allocate resources and prioritize preventive actions accordingly, (iii) anticipation of the potential ecological and economic impacts of invasion, and (iv) formulation of contingency plans for immediate response in the case of invasion. In practice, this entire range of management actions benefits from understanding the species biology, ecology, and invasion history.

While control measures targeted at established invasive bivalves should be viewed as the last resort, often the pests are not acknowledged until such measures are actually necessary.

Research into efficient methods to control invasive bivalves in the industrial environment has been ongoing for the past decades in the public and private sectors as a response to the great economic losses resulting from biofouling (Mackie \& Claudi, 2010). Several control strategies, with varying degree of effectiveness, have been suggested for industrial facilities (Table 2; Mackie \& Claudi, 2010). These strategies can be classified as reactive or proactive. Reactive measures, targeted at adults, are applied when the system is robust enough to tolerate some degree of fouling but has reached a threshold in terms of loss of efficiency. Proactive control methods are targeted at larval stages to inhibit settlement. Chemical treatment, involving the dosing of lethal toxicants or compounds that impair settlement, is the central strategy in most reactive and proactive control programs. This approach tends to be less expensive and more efficient and versatile than other methods; it can be easily applied in existing facilities and allows the protection of the entire system against a range of biofouling organisms. Other chemical-aided mitigation methods include combination treatments, which seek biocidal action enhancement, and chemical cleaning, where proprietary inorganic acid mixtures are used to dissolve the mollusks' shells. Nonchemical control options range from proactive techniques, such as raw water filtration and UV light treatment, to reactive methods, such as mechanical cleaning and mitigation by desiccation.

Cost-effectiveness and environmental impacts are critical issues in industrial settings. In open waters, 
Table 2 Summary of methods available for controlling invasive bivalves in industry (see, for example, Mackie \& Claudi, 2010 for details)

\begin{tabular}{|c|c|c|}
\hline Type & Method & Target \\
\hline \multirow{5}{*}{$\begin{array}{l}\text { Chemical- } \\
\text { aided } \\
\text { control }\end{array}$} & Chemical treatment & \\
\hline & $\begin{array}{l}\text { Oxidizing chemicals chlorine, chlorine dioxide, chloramines, ozone, } \\
\text { bromine, hydrogen peroxide, potassium permanganate, ferrate }\end{array}$ & Frequently used in proactive control \\
\hline & $\begin{array}{l}\text { Non-oxidizing chemicals proprietary formulations (e.g., quaternary } \\
\text { amines, niclosamide), bacteria-based molluscicide (Zequanox }{ }^{\circledR} \text { ), } \\
\text { encapsulated formulations (BioBullets), ammonium nitrate, copper ions, } \\
\text { potassium ions, sodium metabisulfite, coagulants/flocculants, salinity, } \\
\text { agents for pH adjustment }\end{array}$ & $\begin{array}{l}\text { Used in both proactive and reactive } \\
\text { control; some chemicals used } \\
\text { preferably in reactive control only }\end{array}$ \\
\hline & $\begin{array}{l}\text { Combination treatments (combined biocides, temperature-enhanced } \\
\text { chemical treatment) }\end{array}$ & Mainly used in reactive control \\
\hline & Chemical cleaning & Reactive control \\
\hline \multirow{14}{*}{$\begin{array}{l}\text { Non- } \\
\text { chemical } \\
\text { control }\end{array}$} & Infiltration galleries and sand filters & Proactive control \\
\hline & Mechanical filtration & \\
\hline & Ultraviolet light & \\
\hline & Electric current & \\
\hline & Acoustics & \\
\hline & Antifouling and foul release coatings & \\
\hline & High-speed agitators & \\
\hline & Increased speed of flow & \\
\hline & Magnetic field & \\
\hline & Thermal shock & Reactive control \\
\hline & Desiccation & \\
\hline & Freezing following desiccation & \\
\hline & Oxygen deprivation & \\
\hline & Mechanical cleaning & \\
\hline
\end{tabular}

Table 3 Summary of possible methods for controlling invasive bivalves in open waters

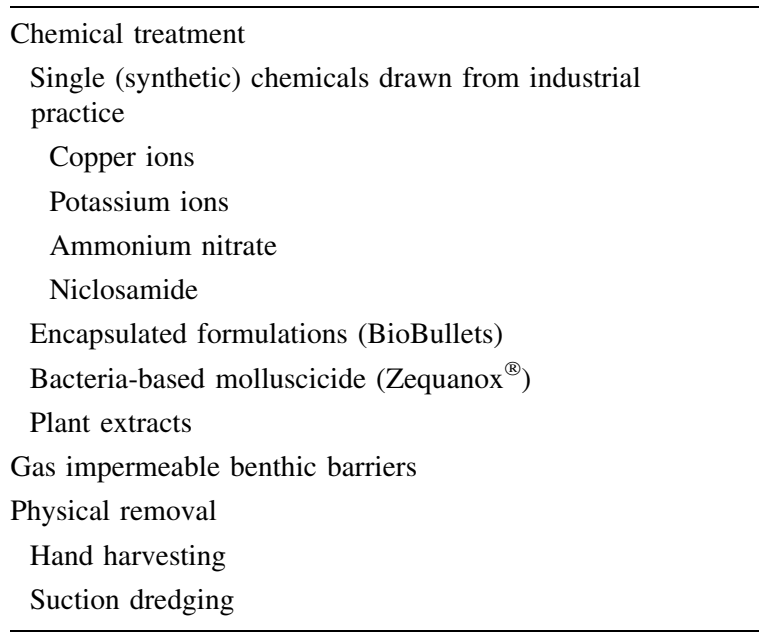

these issues escalate and pest control is even more challenging as mitigation measures have to be applied directly in nature. In fact, both scale-related feasibility aspects, mainly linked to the volume of water and system configuration, and poor selectivity highly limit the direct extension of the industrial control methods available to the ecological context. For example, using UV light (Pickles, 2000) to prevent the settlement of incoming macrofoulers in an uninfested lake is not only physically impractical but also likely to negatively affect the non-target species.

No method to successfully eradicate established or settling invasive bivalves in natural waterbodies has been envisaged thus far. Incipient control strategies along with some research lines that are worth pursuing in this context are outlined below and summarized in Table 3 . 
As in industry, chemical treatment could be a versatile control technique to apply in the ecological context. However, in addition to biocides' ecotoxicity attention should be given to other environmental impacts resulting from the sudden death of dense bivalve populations (through, for example, the reduction of dissolved oxygen content or an increase in ammonia concentration) as well as economical aspects related to high treatment dosages, which should be weighed when considering whether to apply chemical control in open waters.

Even so, under specific circumstances pest managers may opt to accept the detrimental environmental effects and cost-efficiency of biocides regularly used to control the nuisances in industrial plants. For example, the strategy devised to eradicate zebra mussels from the Base Lake at Offutt Air Force Base (Nebraska, USA) involved the application of over 22 ton of copper sulfate pentahydrate to achieve an estimated copper concentration of $1 \mathrm{ppm}$ over two separate treatments in September 2008 and April 2009 (URS, 2009). While preliminary monitoring indicated effective zebra mussel mitigation, the selectivity of the treatment was very poor, with massive fish mortality being reported. As another example, in 2006 almost $131,000 \mathrm{~kg}$ of potassium chloride was applied to eliminate zebra mussels from the approximately 5-ha Millbrook Quarry in Virginia, USA [Virginia Department of Game and Inland Fisheries (VDGIF) 2005, 2009]. The treatment was expected to provide longterm protection against future infestations. The target potassium treatment concentration used (100 ppm) was claimed to pose no risk to non-molluscan wildlife and human health. In fact, by being a relatively selective biocide, the potassium ion has been suggested as an attractive control alternative for use in situations where the survival of non-target bivalves is not a concern, such as in fishery operations (Fisher et al., 1991; Durand-Hoffman, 1995). Ammonium nitrate is also a control agent drawn from industrial practice that may have some applications in the ecological context. While high levels of ammonium nitrate will adversely affect non-target biota, this may be an economical treatment option for use in open agricultural ecosystems where chemical fertilization is already being employed (Coon et al., 1993). The use of niclosamide in open waters under limited and strictly controlled conditions may also be worth considering. This chemical, which can be dosed as the proprietary
Bayluscide WP 70 for instance, has already been applied in the Great Lakes (USA) as part of a chemical control strategy against sea lampreys (Dawson, 2003).

BioBullets consist of a biocide coated by a material edible for the nuisance species, shaped into microscopic particles (Aldridge et al., 2006; Costa et al., 2011). By capitalizing on the bivalves' filtration activity and minimizing their avoidance responses, encapsulated formulations increase their susceptibility to the biocides and allow control to be achieved faster and through lower chemical dosages. This is a very flexible technology and the possibility of tailoring the particles for use in natural environments is worth investigating. BioBullets' structure may be exploited to perform selective mitigation. Not only they allow the use of reduced treatment dosages, harmless to higher organisms but also their potential impacts on non-target filter-feeders may be overcome by targeting the particles at the invasive bivalves through size or coating manipulation for example (Costa et al., 2011).

Zequanox ${ }^{\circledR}$, a bacteria-based molluscicide, is being brought into the market by Marrone Bio Innovations. The product is composed of dead cells of a Pseudomonas fluorescens strain, which contain toxic substances that have been shown to destroy zebra and quagga mussels' digestive systems (Marrone Bio Innovations, 2012a, b). Zequanox ${ }^{\circledR}$ is claimed to be highly selective, being non-toxic to a wide range of non-target organisms, including fish, ciliates, daphnids, and unionid mussels, at dosages that provide adequate pest control (Marrone Bio Innovations, 2012b). Moreover, the product derives from a naturally occurring, harmless, worldwide distributed bacterial species and contains no living organisms, which further reduces environmental concerns. For these reasons, this novel technology, so far recommended for application in industry, may also have potential to control invasive bivalves in open waters.

The possibility of eradicating invasive bivalves through natural control agents based on plant extracts, which are already employed in other pest mitigation contexts (e.g., see Isman, 2000), is worth investigating. Preliminary results showed that thyme essential oil and extracts obtained from an Eichhornia species are promising as control agents against $C$. fluminea (Costa, unpublished data). While such substances may be prohibitively expensive for application in bulk, relatively lower impacts on non-target species may justify designed delivery strategies, for example through encapsulation (Costa et al., 2011). 
The detrimental impact on non-target taxa is one of the major challenges in applying chemical treatment. Therefore the search for new, more selective biocides (as the active ingredients in Zequanox ${ }^{\circledR}$ ) and the development of novel delivery methods to target the chemicals to the nuisance species (as biocide encapsulation) are research topics of interest. As another example within this research scope, Perry \& Lynn (2009) attempted to link changes in apoptotic patterns in invasive bivalves' early developmental stages to biocide exposure to identify minimal treatment dosages that would disrupt bivalves' development while reducing environmental impacts.

Beyond chemical control strategies, some nonchemical treatment options may be applied in open waters, although the latter can easily become logistically less practical than biocide dosing. One of such strategies is the use of gas impermeable benthic barriers, for example made of polyvinyl chloride, which induce the bivalves' mortality primarily by limiting the dissolved oxygen available (Wittmann et al., 2012). Naturally, non-target organisms are also negatively affected by oxygen depletion. While this method seem to have produced promising results on C. fluminea control in Lake Tahoe (California and Nevada, USA; Wittmann et al., 2012) and certain areas of Lake George [New York, USA; Lake George Asian Clam Rapid Response Task Force (LGACRRTF), 2012], its application is compromised by specific bottom conditions, such as the presence of boulders and other impediments (LGACRRTF, 2012).

The removal of colonizing bivalves by hand harvesting may be a viable control approach if the invasion is detected early and the species is still confined to a relatively small area. For example, zebra mussels seem to have been successfully eradicated from Lake George through the efforts of SCUBA divers, who reduced the density of the incipient population to a level that impeded reproduction and sustained recruitment (Wimbush et al., 2009). Alternatively to the manual method, physical removal of invasive bivalve populations may be conducted by suction dredging; a technique that also has high nontarget impacts (LGACRRTF, 2012).

As a wide range of species, including fish, birds, and crustaceans among others, have been observed to prey on invasive bivalves (Molloy et al., 1997) there is often a propensity to consider biological control as a possible approach. Under specific conditions, it is conceivable that predators can in fact be used to hamper the development of new populations, especially during the lag time phase of colonization. For example, fish, such as the freshwater drum Aplodinotus grunniens (French \& Bur, 1993) and the roach Rutilus rubilio (Prejs et al., 1990) may contribute to the mitigation of zebra mussels in irrigation canals or small lakes. However, in general predators should not be expected to be capable of completely eliminating and sustainably controlling the nuisance bivalves by themselves (Molloy et al., 1997).

The complete eradication of established invasive bivalve populations is extremely difficult and no control method should be regarded as miraculous. Even if the control action immediately results in high mortality or removal, subsequent monitoring for an extended period of time, complemented by preventive measures against reintroductions and regular treatments as needed, are essential. Furthermore, as all control methods may affect the ecosystem, restoration should be a primary concern and non-target taxa recolonization patterns should always be accompanied after eradication measures are applied.

\section{Conclusion and future challenges}

Invasive freshwater bivalves can be responsible for great ecological impacts, from the individual to the ecosystem level, as well as economic impacts in invaded areas. This situation was responsible for increased scientific, social, and management interest in this faunal group and knowledge about invasive bivalve species advanced greatly in the last two decades. However, much remains to be done to understand and mitigate their major impacts and some aspects clearly deserve further attention in the future; below we outline some of these aspects.

Most studies were done in North America and Europe and this of course not only reflects the great degree of invasion to which these continents are subjected but also a higher financial investment in scientific research. However, South America, Asia and Africa are far from being immune to impacts generated by invasive bivalves and there is a great need to increase the number of studies on these continents. Also important to note is the small number of studies (at least published in peer-reviewed journals) done in the native range of these invasive bivalves. This is 
regrettable because such knowledge may be essential to find ways to mitigate the major problems they provoke. Better and enhanced cooperation between scientists from the invaded and the native ranges is necessary and future scientific studies should take this into account. In addition, there is a great need to have comparable data between different continents. Indeed, differences in methodology have hindered our ability to further evaluate impacts and this situation has to be addressed in the future.

Attention should also be given to hybridization between closely related taxa or between genetically differentiated populations. This may pose a serious threat to biodiversity and remains unexplored.

Given that some of the most important impacts of these bivalve species are related to filter-feeding, it is essential to develop the ability to estimate these rates in nature (Reeders \& Bij De Vaate, 1990, 1992). Although filter-feeding might, at first, seem a relatively simple process, closer examination shows a wide discrepancy between the particles in the medium and the food actually retained and assimilated. This discrepancy deserves attention. In the same vein, the majority of studies assessing filtration rates were performed under laboratory conditions, which may underestimate filtration rates. In addition, there is a paucity of studies addressing the impact of these bivalves on bacterioplankton and this should also be an avenue of future research.

Usually, the majority of studies address the ecological or economic effects of single species. However, given the widespread distribution of some of these species, their distributions in some places already overlap (and the probability of overlap will increase in the future) and so will be very interesting to assess the possible ecological and economic effects when two or more of these invasive bivalves inhabit the same ecosystem. These effects may be additive, or we may observe synergistic or antagonistic effects.

In terms of management, it will be important that new approaches and techniques that have been developed could be assessed not only for industry but also for natural ecosystems. For example, early detection can be improved by innovative tools such as environmental DNA (Ficetola et al., 2008; Jerde et al., 2011). These techniques are becoming cheaper and will certainly increase our ability to detect an incipient invasion early which may increase the chances of rapid responses to eradicate or contain the spread of the target species.
Finnally, the number of long-term studies addressing invasive bivalves (but also other taxonomic groups) and their impacts is still very low. In many cases, we may take advantage of knowing the exact time of introduction of these bivalve species and so assess the major mechanisms of change directly. Therefore, invasive bivalves may be very interesting models to be used in overall invasion science.

Acknowledgments This study was conducted in the scope of the project "ECO-IAS", funded by the Portuguese Foundation for the Science and the Technology and COMPETE funds (Contract: PTDC/AAC-AMB/116685/2010).

\section{References}

Aldridge, D. C., P. Elliot \& G. D. Moggridge, 2004. The recent and rapid spread of the zebra mussel (Dreissena polymorpha) in Great Britain. Biological Conservation 119: 253-261.

Aldridge, D. C., P. Elliott \& G. D. Moggridge, 2006. Microencapsulated BioBullets for the control of biofouling zebra mussels. Environmental Science and Technology 40: 975-979.

Bastviken, D. T. E., N. F. Caraco \& J. J. Cole, 1998. Experimental measurements of zebra mussel (Dreissena polymorpha) impacts on phytoplankton community composition. Freshwater Biology 39: 375-386.

Benson, A., 2012. USGS Nonindigenous Aquatic Species Database, Gainesville, FL [available on internet at http://nas.er. usgs.gov/queries/SpeciesList.aspx?Group=Mollusks. Accessed 31 May 2012].

Bódis, E., B. Tóth \& R. Sousa, 2013. Massive mortality of invasive bivalves as a potential resource subsidy for the adjacent terrestrial food web. Hydrobiologia (in press).

Boltovskoy, D., N. Correa, D. Cataldo \& F. Sylvester, 2006. Dispersion and ecological impact of the invasive freshwater bivalve Limnoperna fortunei in the Río de la Plata watershed and beyond. Biological Invasions 8: 947-963.

Boltovskoy, D., A. Karatayev, L. Burlakova, D. Cataldo, V. Karatayev, F. Sylvester \& A. Mariñelarena, 2009. Significant ecosystem-wide effects of the swiftly spreading invasive freshwater bivalve Limnoperna fortunei. Hydrobiologia 636: 271-284.

Byers, J. E., 2002. Impact of non-indigenous species enhanced by anthropogenic alteration of selection regimes. Oikos 97: 449-458.

Cantanhêde, G., N. S. Hahn, É. A. Gubiani \& R. Fugi, 2008. Invasive molluscs in the diet of Pterodoras granulosus (Valenciennes, 1821) (Pisces, Doradidae) in the Upper Paraná River floodplain, Brazil. Ecology of Freshwater Fish 17: 47-53.

Caraco, N. F., J. J. Cole, P. A. Raymond, D. L. Strayer, M. L. Pace, S. E. G. Findlay \& D. T. Fischer, 1997. Zebra mussel invasion in a large, turbid river: phytoplankton response to increased grazing. Ecology 78: 588-602.

Caraco, N. F., J. J. Cole \& D. L. Strayer, 2006. Top down control from the bottom: regulation of eutrophication in a large 
river by benthic grazing. Limnology and Oceanography 51: 664-670.

Carlsson, N. O. L., O. Sarnelle \& D. L. Strayer, 2009. Native predators and exotic prey-an acquired taste? Frontiers in Ecology and the Environment 7: 525-532.

Carlsson, N. O. L., H. Bustamante, D. L. Strayer \& M. L. Pace, 2011. Biotic resistance on the increase: native predators structure invasive zebra mussel populations. Freshwater Biology 56: 1630-1637.

Carlton, J. T., 1993. Dispersal mechanisms of the zebra mussel (Dreissena polymorpha). In Nalepa, T. F. \& D. W. Schloesser (eds), Zebra Mussels: Biology, Impacts and Control. Lewis, Boca Raton: 677-697.

Cherry, D. S., J. L. Scheller, N. L. Cooper \& J. R. Bidwell, 2005. Potential effects of Asian clam (Corbicula fluminea) dieoffs on native freshwater mussels (Unionidae) I: watercolumn ammonia levels and ammonia toxicity. Journal of the North American Benthological Society 24: 369-380.

Clavero, M., R. Araújo, J. Calzada, M. Delibes, N. Fernández, C. Gutiérrez-Expósito, E. Revilla \& J. Román, 2012. The first invasive bivalve in African freshwaters: invasion portrait and management options. Aquatic Conservation: Marine and Freshwater Ecosystems 22: 277-280.

Clayton, J. L., C. W. Stihler \& J. L. Wallace, 2001. Status and potential impacts to the freshwater bivalves (Unionidae) in Patterson Creek, West Virginia. Northeast Naturalist 8: 179-188.

Cohen, A. N. \& J. T. Carlton, 1998. Accelerating invasion rate in a highly invaded estuary. Science 279: 555-558.

Connelly, N. A., C. R. O’Neill, B. A. Knuth \& T. L. Brown, 2007. Economic impacts of zebra mussels on drinking water treatment and electric power generation facilities. Environmental Management 40: 105-112.

Coon, G. T., H. W. Belcher, D. J. Harston \& Y. Zai-Chun, 1993. Potential infestation of subirrigation systems in Saginaw Bay by zebra mussels and evaluation of control options. Presented at the 3rd International Zebra Mussel Conference, Toronto.

Cooper, N. L., J. R. Bidwell \& D. S. Cherry, 2005. Potential effects of Asian clam (Corbicula fluminea) die-offs on native freshwater mussels (Unionidae) II: pore-water ammonia. Journal of the North American Benthological Society 24: 381-394.

Costa, R., D. Aldridge \& G. D. Moggridge, 2011. Preparation and evaluation of biocide-loaded particles to control the biofouling zebra mussel, Dreissena polymorpha. Chemical Engineering Research and Design 89: 2322-2329.

Cox, G. W., 2004. Alien Species and Evolution. Island Press, Washington, DC.

Darrigran, G., 2002. Potential impact of filter-feeding invaders on temperate inland freshwater environments. Biological Invasions 4: 145-156.

Dawson, V. K., 2003. Environmental fate and effects of the lampricide Bayluscide: a review. Journal of Great Lakes Research 29: 475-492.

Dudgeon, D., A. H. Arthington, M. O. Gessner, Z. Kawabata, D. J. Knowler, C. Lévêque, R. J. Naiman, A. Prieur-Richard, D. Soto, M. L. J. Stiassny \& C. A. Sullivan, 2006. Freshwater biodiversity: importance, threats, status and conservation challenges. Biological Reviews 81: 163-182.
Duffy, J. E., 2009. Why biodiversity is important to the functioning of real-world ecosystems. Frontiers in Ecology and the Environment 7: 437-444.

Durand-Hoffman, M. E., 1995. Analysis of physiological and toxicological effects of potassium on Dreissena polymorpha and toxicological effects on fish. MS thesis, Ohio State University, Columbus.

Ehrenfeld, J. G., 2010. Ecosystem consequences of biological invasions. Annual Review of Ecology, Evolution, and Systematics 41: 59-80.

Essl, F., S. Dullinger, W. Rabitsch, P. E. Hulme, K. Hülber, V. Jarošík, I. Kleinbauer, F. Krausmann, I. Kühn, W. Nentwig, M. Vilà, P. Genovesi, F. Gherardi, M.-L. Desprez-Loustau, A. Roques \& P. Pyšek, 2011. Socioeconomic legacy yields an invasion debt. Proceedings of the National Academy of Sciences of the United States of America 108: 203-207.

Fernald, S. H., N. F. Caraco \& J. J. Cole, 2007. Changes in cyanobacterial dominance following the invasion of the zebra mussel Dreissena polymorpha: long-term results from the Hudson River estuary. Estuaries and Coasts 30: 163-170.

Ficetola, G. F., C. Miaud, F. Pompanon \& P. Taberlet, 2008. Species detection using environmental DNA from water samples. Biology Letters 4: 423-425.

Finnoff, D., J. F. Shogren, B. Leung \& D. Lodge, 2007. Take a risk: preferring prevention over control of biological invaders. Ecological Economics 62: 216-222.

Fisher, S. W., P. Stromberg, K. A. Bruner \& L. D. Boulet, 1991. Molluscicidal activity of potassium to the zebra mussel, Dreissena polymorpha-toxicity and mode of action. Aquatic Toxicology 20: 219-234.

French, J. R. P. III., \& M. T. Bur, 1993. Predation of the zebra mussel (Dreissena polymorpha) by freshwater drum in western Lake Erie. In Nalepa, T. F. \& D. W. Schloesser (eds), Zebra Mussels: Biology, Impacts and Control. Lewis, Boca Raton: 453-464.

Garcia, M. L. \& L. C. Protogino, 2005. Invasive freshwater molluscs are consumed by native fishes in South America. Journal of Applied Ichthyology 21: 34-38.

Haag, W. R., D. J. Berg, D. W. Garton \& J. L. Farris, 1993. Reduced survival and fitness in native bivalves in response to fouling by the introduced zebra mussel (Dreissena polymorpha) in western Lake Erie. Canadian Journal of Fisheries and Aquatic Sciences 50: 13-19.

Hamilton, D. J., C. D. Ankney \& R. C. Bailey, 1994. Predation of zebra mussels by diving ducks: an enclosure approach. Ecology 75: 521-531.

Higgins, S. N. \& M. J. Vander Zanden, 2010. What a difference a species makes: a meta-analysis of dreissenid mussel impacts on freshwater ecosystems. Ecological Monographs 80: 179-196.

Hulme, P. E., P. Pysek, W. Nentwig \& M. Vilà, 2009. Will threat of biological invasions unite the European Union? Science 324: 40-41.

Ilarri, M. \& R. Sousa, 2012. Corbicula fluminea Müller (Asian clam). In Francis, R. A. (ed.), A Handbook of Global Freshwater Invasive Species. Earthscan, London: 173-183.

Ilarri, M., C. Antunes, L. Guilhermino \& R. Sousa, 2011. Massive mortality of the Asian clam Corbicula fluminea in a highly invaded area. Biological Invasions 13: 277-280. 
Ilarri, M., F. Freitas, S. Costa-Dias, C. Antunes, L. Guilhermino \& R. Sousa, 2012. Associated macrozoobenthos with the invasive Asian clam Corbicula fluminea. Journal of Sea Research 72: 113-120.

Isman, M. B., 2000. Plant essential oils for pest and disease management. Crop Protection 19: 603-608.

Jerde, C. L., A. R. Mahon, W. L. Chadderton \& D. M. Lodge, 2011. "Sight-unseen" detection of rare aquatic species using environmental DNA. Conservation Letters 4: 150-157.

Jones, C. G., J. H. Lawton \& M. Shachak, 1994. Organisms as ecosystem engineers. Oikos 69: 373-386.

Karatayev, A. Y., L. E. Burlakova \& D. K. Padilla, 1997. The effects of Dreissena polymorpha (Pallas) invasion on aquatic communities in Eastern Europe. Journal of Shellfish Research 16: 187-203.

Karatayev, A. Y., D. Boltovskoy, D. K. Padilla \& L. E. Burlakova, 2007. The invasive bivalves Dreissena polymorpha and Limnoperna fortunei: parallels, contrasts, potential spread and invasion impacts. Journal of Shellfish Research 26: 205-213.

Kat, P. W., 1986. Hybridization in a unionid faunal suture zone. Malacologia 27: 107-126.

Keller, R. P., D. M. Lodge \& D. C. Finnoff, 2007a. Risk assessment for invasive species produces net bioeconomic benefits. Proceedings of the National Academy of Sciences 104: 203-207.

Keller, R. P., J. M. Drake \& D. M. Lodge, 2007b. Fecundity as a basis for risk assessment of nonindigenous freshwater molluscs. Conservation Biology 21: 191-200.

Kolar, C. S. \& D. M. Lodge, 2002. Ecological predictions and risk assessment for alien fishes in North America. Science 298: 1233-1236.

Lajtner, J. \& P. Crnčan, 2011. Distribution of the invasive bivalve Sinanodonta woodiana (Lea, 1834) in Croatia. Aquatic Invasions 6: S119-S124.

Lake George Asian Clam Rapid Response Task Force (LGACRRTF), 2012. Lake George Asian clam containment and eradication project: report on 2011 activities and 2012 plan [available on internet at http://www.lcbp.org/ PDFs/LGACRRTF_2011_Report\%20_2012_Plan.pdf. Accessed 8 June 2012].

Mackie, G. L. \& R. Claudi, 2010. Monitoring and Control of Macrofouling Mollusks in Fresh Water Systems. CRC Press, Boca Raton.

Mansur, M., C. dos Santos, D. Pereira, I. Paz, M. Zurita, M. Rodriguez, M. Nehrke \& P. Bergonci, 2012. Moluscos límnicos invasores no Brasil: biologia, prevenção, controle. Redes Editora, Porto Alegre.

Marrone Bio Innovations, 2012a. Zequanox ${ }^{\circledR}$ - Invasive mussel control [available on internet at http://www.marronebio innovations.com/pdf/ZequanoxFlyer.pdf. Accessed 8 June 2012].

Marrone Bio Innovations, 2012b. ZEQUANOX ${ }^{\mathrm{TM}}$-Environmentally friendly biological control of zebra and quagga mussels with Pseudomonas fluorescens strain CL145A [available on internet at http://www.marronebioinnova tions.com/pdf/zequanox_bg2.pdf. Accessed 8 June 2012].

McMahon, R. F., 1982. The occurrence and spread of the introduced Asiatic freshwater clam, Corbicula fluminea (Müller) in North America, 1924-1982. Nautilus 96: 134-141.
McMahon, R. F., 2002. Evolutionary and physiological adaptations of aquatic invasive animals: $r$ selection versus resistance. Canadian Journal of Fisheries and Aquatic Sciences 59: 1235-1244.

Mills, E. L., J. H. Leach, J. T. Carlton \& C. L. Secor, 1993. Exotic species in the Great Lakes: a history of biotic crises and anthropogenic introductions. Journal of Great Lakes Research 19: 1-54.

Mills, E. L., G. Rosenberg, A. P. Spidle, M. Ludyanskiy, Y. Pligin \& B. May, 1996. A review of the biology and ecology of the quagga mussel (Dreissena bugensis), a second species of freshwater Dreissenid introduced to North America. American Zoologist 36: 271-286.

Mills, E. L., J. T. Carlton, M. D. Scheuerell \& D. L. Strayer, 1997. Biological invasions in the Hudson River: an inventory and historical analysis. New York State Museum Circular 57: 1-51.

Molloy, D. P., A. Y. Karatayev, L. E. Burlakova, D. P. Kurandina \& F. Laruelle, 1997. Natural enemies of zebra mussels: predators, parasites and ecological competitors. Reviews in Fisheries Science 5: 27-97.

Morrison, H. A., F. A. P. C. Gobas, R. Lazar, D. M. Whittle \& G. D. Haffner, 1998. Projected changes to the trophodynamics of PCBs in the western Lake Erie ecosystem attributed to the presence of zebra mussels (Dreissena polymorpha). Environmental Science and Technology 32: 3862-3867.

Mouthon, J., 1981. Sur la présence en France et au Portugal de Corbicula (Bivalvia, Corbiculidae) originaire d'Asie. Basteria 45: 109-116.

Nalepa, T. F., D. L. Fanslow \& G. A. Lang, 2009. Transformation of the offshore benthic community in Lake Michigan: recent shift from the native amphipod Diporeia spp. to the invasive mussel Dreissena rostriformis bugensis. Freshwater Biology 54: 466-479.

Nichols, S. J. \& D. A. Wilcox, 1997. Burrowing saves Lake Erie clams. Nature 389: 921.

Ogawa, K., T. Nakatsugawa \& I. M. Yasuzaki, 2004. Heavy metacercarial infections of cyprinid fishes in Uji River. Fisheries Science 70: 132-140.

Pace, M. L., D. L. Strayer, D. T. Fischer \& H. M. Malcom, 2010. Increased mortality of zebra mussels associated with recovery of zooplankton in the Hudson River. Ecosphere 1: art3.

Paolucci, E. M., D. H. Cataldo, C. M. Fuentes \& D. Boltovskoy, 2007. Larvae of the invasive species Limnoperna fortunei (Bivalvia) in the diet of fish larvae in the Paraná River, Argentina. Hydrobiologia 589: 219-233.

Paolucci, E. M., E. V. Thuesen, D. H. Cataldo \& D. Boltovskoy, 2010. Veligers of an introduced bivalve, Limnoperna fortunei, are a new food resource that enhances growth of larval fish in the Paraná River (South America). Freshwater Biology 55: 1831-1844.

Pérez-Fuentetaja, A., M. D. Clapsadl, D. Einhouse, P. R. Bowser, R. G. Getchell \& W. T. Lee, 2006. Influence of limnological conditions on Clostridium botulinum type $\mathrm{E}$ presence in Eastern Lake Erie sediments (Great Lakes, USA). Hydrobiologia 563: 189-200.

Perry, K. \& J. Lynn, 2009. Detecting physiological and pesticide-induced apoptosis in early developmental stages of invasive bivalves. Hydrobiologia 628: 153-154.

Perry, W. L., D. M. Lodge \& J. L. Feder, 2002. Importance of hybridization between indigenous and nonindigenous 
freshwater species: an overlooked threat to North American biodiversity. Systematic Biology 51: 255-275.

Phelps, H. L., 1994. The Asiatic clam (Corbicula fluminea) invasion and system-level ecological change in the Potomac river estuary near Washington, D.C. Estuaries 17: 614-621.

Pickles, S. B., 2000. Use of ultraviolet radiation for zebra mussel control at Ontario power generation. Presented at the 10th International Aquatic Nuisances Species and Zebra Mussel Conference, Toronto.

Pigneur, L. M., J. Marescaux, K. Roland, E. Etoundi, J. P. Descy \& K. Van Doninck, 2011. Phylogeny and androgenesis in the invasive Corbicula clams (Bivalvia, Corbiculidae) in Western Europe. BMC Evolutionary Biology 11: 147.

Pimentel, D., L. Lach, R. Zuniga \& D. Morrison, 2000. Environmental and economic costs of nonindigenous species in the United States. BioScience 50: 53-65.

Prejs, A., K. Lewandowski \& A. Stanczykowska-Piotrowska, 1990. Size-selective predation by roach (Rutilus rutilus) on zebra mussel (Dreissena polymorpha): field studies. Oecologia 83: 378-384.

Prokopovich, N. P. \& D. J. Herbert, 1965. Sedimentation in the Delta-Mendota Canal. Journal of American Water Works Association 57: 375-382.

Reeders, H. H. \& A. Bij de Vaate, 1990. Zebra mussels (Dreissena polymorpha): a new perspective for water quality management. Hydrobiologia 200/201: 437-450.

Reeders, H. H. \& A. Bij de Vaate, 1992. Bioprocessing of polluted suspended matter from the water column by the zebra mussel (Dreissena polymorpha Pall.). Hydrobiologia 239: 53-63.

Reichard, M., M. Vrtílek, K. Douda \& C. Smith, 2012. An invasive species reverses the roles in a host-parasite relationship between bitterling fish and unionid mussels. Biology Letters 8: 601-604.

Rhymer, J. M. \& D. Simberloff, 1996. Extinction by hybrization and introgression. Annual Review of Ecology, Evolution, and Systematics 27: 83-109.

Ricciardi, A., F. G. Whoriskey \& J. B. Rasmussen, 1997. The role of the zebra mussel (Dreissena polymorpha) in structuring macroinvertebrate communities on hard substrata. Canadian Journal of Fisheries and Aquatic Sciences 54: 2596-2608.

Ricciardi, A., R. J. Neves \& J. B. Rasmussen, 1998. Impending extinctions of North American freshwater mussels (Unionoida) following the zebra mussel (Dreissena polymorpha) invasion. Journal of Animal Ecology 67: 613-619.

Richardson, D. M. \& P. Pyšek, 2008. Fifty years of invasion ecology - the legacy of Charles Elton. Diversity and Distributions 14: 161-168.

Riley, S. C., K. R. Munkittrick, A. N. Evans \& C. C. Krueger, 2008. Understanding the ecology of disease in Great Lakes fish populations. Aquatic Ecosystem Health and Management 11: 321-334.

Roditi, H. A., D. L. Strayer \& S. E. G. Findlay, 1997. Characteristics of zebra mussel (Dreissena polymorpha) biodeposits in a tidal freshwater estuary. Archiv für Hydrobiologie 140: 207-219.

Schloesser, D. W., T. F. Nalepa \& G. L. Mackie, 1996. Infestation of unionid bivalves (Unionidae) in North America. American Zoologist 36: 300-310.
Simberloff, D., 2009. The role of propagule pressure in biological invasions. Annual Review of Ecology, Evolution, and Systematics 40: 81-102.

Simberloff, D., 2011. How common are invasion-induced ecosystem impacts? Biological Invasions 13: 1255-1268.

Simberloff D., J.-L. Martin, J. Aronson, F. Courchamp, B. Galil, E. Garcia-Berthou, P. Genovesi, V. Maris, M. Pascal, P. Pyšek, R. Sousa, E. Tabacchi, M. Vilà \& D. Wardle, 2013. Impacts of biological invasions - what's what and the way forward. Trends in Ecology and Evolution (in press).

Smith, C., M. Reichard, P. Jurajda \& M. Przybylski, 2004. The reproductive ecology of the European bitterling (Rhodeus sericeus). Journal of Zoology 262: 107-124.

Sousa, R., C. Antunes \& L. Guilhermino, 2008a. Ecology of the invasive Asian clam Corbicula fluminea (Müller, 1774) in aquatic ecosystems: an overview. Annales de Limnologie-International Journal of Limnology 44: 43-52.

Sousa, R., A. J. A. Nogueira, M. Gaspar, C. Antunes \& L. Guilhermino, 2008b. Growth and extremely high production of the non-indigenous invasive species Corbicula fluminea (Müller, 1774): possible implications for ecosystem functioning. Estuarine, Coastal and Shelf Science 80: 289-295.

Sousa, R., J. L. Gutiérrez \& D. C. Aldridge, 2009. Non-indigenous invasive bivalves as ecosystem engineers. Biological Invasions 11: 2367-2385.

Sousa, R., P. Morais, E. Dias \& C. Antunes, 2011a. Biological invasions and ecosystem functioning: time to merge. Biological Invasions 13: 1055-1058.

Sousa, R., F. Pilotto \& D. C. Aldridge, 2011b. Fouling of European freshwater bivalves (Unionidae) by the invasive zebra mussel (Dreissena polymorpha). Freshwater Biology 56: 867-876.

Sousa, R., S. Varandas, R. Cortes, A. Teixeira, M. Lopes-Lima, J. Machado \& L. Guilhermino, 2012. Massive die-offs of freshwater bivalves as resource pulses. Annales de Limnologie-International Journal of Limnology 48: 105-112.

Stewart, A. R., S. N. Luoma, C. E. Schlekat, M. A. Doblin \& K. A. Hieb, 2004. Food web pathway determines how selenium affects aquatic ecosystems: a San Francisco Bay case study. Environmental Science and Technology 38: 4519-4526.

Stohlgren, T. J., D. Binkley, G. W. Chong, M. A. Kalkhan, L. D. Schell, K. A. Bull, Y. Otsuki, G. Newman, M. Bashkin \& Y. Son, 1999. Exotic plant species invade hot spots of native plant diversity. Ecological Monographs 69: 25-46.

Strayer, D. L., 1999. Effects of alien species on freshwater mollusks in North America. Journal of the North American Benthological Society 18: 74-98.

Strayer, D. L., 2009. Twenty years of zebra mussels: lessons from the mollusk that made headlines. Frontiers in Ecology and the Environment 7: 135-141.

Strayer, D. L., 2010. Alien species in fresh waters: ecological effects, interactions with other stressors, and prospects for the future. Freshwater Biology 55: 152-174.

Strayer, D. L., 2012. Eight questions about invasions and ecosystem functioning. Ecology Letters 15: 1199-1210.

Strayer, D. L. \& A. R. Fetterman, 1999. Changes in the distribution of freshwater mussels (Unionidae) in the upper Susquehanna River Basin, 1955-1965. American Midland Naturalist 142: 328-339. 
Strayer, D. L. \& K. J. Jirka, 1997. The pearly mussels of New York State. New York State Museum Memoir 26: $1-113$.

Strayer, D. L. \& H. M. Malcom, 2007. Effects of zebra mussels (Dreissena polymorpha) on native bivalves: the beginning of the end or the end of the beginning? Journal of the North American Benthological Society 26: 111-122.

Strayer, D. L. \& L. C. Smith, 2001. The zoobenthos of the freshwater tidal Hudson River and its response to the zebra mussel (Dreissena polymorpha) invasion. Archiv für Hydrobiologie Supplementband 139: 1-52.

Strayer, D. L., N. F. Caraco, J. J. Cole, S. Findlay \& M. L. Pace, 1999. Transformation of freshwater ecosystems by bivalves: a case study of zebra mussels in the Hudson River. BioScience 49: 19-27.

Strayer, D. L., K. Hattala \& A. Kahnle, 2004. Effects of an invasive bivalve (Dreissena polymorpha) on fish populations in the Hudson River estuary. Canadian Journal of Fisheries and Aquatic Sciences 61: 924-941.

Strayer, D. L., V. T. Eviner, J. M. Jeschke \& M. L. Pace, 2006. Understanding the long-term effects of species invasions. Trends in Ecology and Evoluion 21: 645-651.

Sylvester, F., D. Boltovskoy \& D. Cataldo, 2007a. Fast response of freshwater consumers to a new trophic resource: predation on the recently introduced Asian bivalve Limnoperna fortunei in the lower Paraná River, South America. Austral Ecology 32: 403-415.

Sylvester, F., D. Boltovskoy \& D. Cataldo, 2007b. The invasive bivalve Limnoperna fortunei enhances benthic invertebrate densities in South American floodplain rivers. Hydrobiologia 589: 15-27.

URS Group, Inc. (URS), 2009. Zebra mussel eradication project. Final summary report, Nebraska [available on internet at http://www.aquaticnuisance.org/wordpress/wp-content/ uploads/2009/01/OAFB-ZM-Final-Summary-Report.pdf. Accessed 8 June 2012].

Vilà, M., C. Basnou, P. Pyšek, M. Josefsson, P. Genovesi, S. Gollasch, W. Nentwig, S. Olenin, A. Roques, D. Roy, P. Hulme \& DAISIE partners, 2010. How well do we understand the impacts of alien species on ecosystem services? A pan-European cross-taxa assessment. Frontiers in Ecology and the Environment 8: 135-144.

Virginia Department of Game and Inland Fisheries (VDGIF), 2005. Millbrook Quarry zebra mussel and quagga mussel eradication. Final environmental assessment, Virginia [available on internet at http://www.dgif.virginia.gov/ wildlife/final_zm_ea.pdf. Accessed 8 June 2012].

Virginia Department of Game and Inland Fisheries (VDGIF), 2009. Millbrook Quarry zebra mussel eradication [available on internet at http://www.dgif.virginia.gov/zebra mussels. Accessed 8 June 2012].

Ward, J. M. \& A. Ricciardi, 2007. Impacts of Dreissena invasions on benthic macroinvertebrate communities: a metaanalysis. Diversity and Distributions 13: 155-165.

Werner, S., M. Mörtl, H.-G. Bauer \& K.-O. Rothhaupt, 2005. Strong impact of wintering waterbirds on zebra mussel (Dreissena polymorpha) populations at Lake Constance, Germany. Freshwater Biology 50: 1412-1426.

Wimbush, J., M. E. Frischer, J. W. Zarzynski \& S. A. NierzwickiBauer, 2009. Eradication of colonizing populations of zebra mussels (Dreissena polymorpha) by early detection and SCUBA removal: Lake George, NY. Aquatic Conservation: Marine and Freshwater Ecosystems 19: 703-713.

Wittmann, M. E., S. Chandra, J. E. Reuter, S. G. Schladow, B. C. Allen \& K. J. Webb, 2012. The control of an invasive bivalve, Corbicula fluminea, using gas impermeable benthic barriers in a large natural lake. Environmental Management 6: 1163-1173.

Zhu, B., D. G. Fitzgerald, C. M. Mayer, L. G. Rudstam \& E. L. Mills, 2006. Alteration of ecosystem function by zebra mussels in Oneida Lake: impacts on submerged macrophytes. Ecosystems 9: 1017-1028.

Zhulidov, A. V., A. V. Kozhara, G. H. Scherbina, T. F. Nalepa, A. Protasov, S. A. Afanasiev, E. G. Pryanichnikova, D. A. Zhulidov, T. Y. Gurtovaya \& D. F. Pavlov, 2010. Invasion history, distribution, and relative abundances of Dreissena bugensis in the old world: a synthesis of data. Biological Invasions 12: 1923-1940. 